\title{
Environmental Statistics at the CZSO: Past Development and Future Trends
}

\author{
Iva Ritschelová ${ }^{1,2}$, Egor Sidorov $^{1,2}$, and Jiří Hřebíček ${ }^{3}$ \\ ${ }^{1}$ Czech Statistical Office, Na padesátém 81, \\ 10082 Praha 10, Czech Republic \\ ${ }^{2}$ Jan Evangelista Purkyně University, Faculty of Environment \\ Králova výšina 3132/7, 40096 Ústí nad Labem, Czech Republic \\ ${ }^{3}$ Masaryk University, Institute of Biostatistics and Analyses \\ Kotlářská 2, 61137 Brno, Czech Republic \\ iva.ritschelova@czso.cz, egor.sidorov@ujep.cz, \\ hrebicek@iba.muni.cz
}

\begin{abstract}
One of the very important aims of the Czech Statistical Office (CZSO) is to produce national statistical data on environmental development among others. During the last two decades one could trace the constantly increasing interest and attention to environmental statistics both at the international, national and regional level. Being a sustainability management tool, its content has been consequently improving and extending along with the changing political priorities and stakeholder interests. The paper describes the development path of the environmental statistics at the CZSO, makes an assessment of its historical development, current state, and presents the expected future development trends in the field.
\end{abstract}

Keywords: environment, statistics, history, development, Czech Republic.

\section{Introduction}

The Czech Statistical Office (CZSO) is an official national statistical institution of the Czech Republic. Being a coordinator of the State Statistical Service its main goal consists in acquisition of data and consequent production of statistical information on social, economic, demographic, and environmental development of the state. Based on acquired data CZSO yields a reliable and consistent image about the state of the arts and development of the society according to various user needs.

The recent stress laid on environmental protection stimulated by discussions and policies both at international and national levels leads to the stable demand for high quality environmentally related statistics from the variety of stakeholders. This interest is primarily motivated by the need to assess the environmental state as well as to define and describe environmental-economic interrelations that are highly influencing economic activity, employment, foreign trade, price level, etc. This is undoubtedly the reason for growing interest among politicians, as well as businessmen in the range of quality environmentally related statistics suitable for complex environmental-economic analyses. 
In reaction to this demand the CZSO has been actively developing production of environmentally related statistics. The following paper maps the main factors that have influenced its recent development and present a bottom line of its current state. The special attention is devoted to key factors and trends that are expected to significantly influence future development in the field.

\section{Development of the Environmental Statistics at the CZSO}

Legislation development may be considered to be one of the most significant factors influencing the content of the official environmental statistics produced by the CZSO. Concerning the development of the Czech state environmental policy before 1989 one can mention several legislative acts focused on water, forests and general nature protection that appeared in 1950's. In 1960's the land and air legislation came into being. In 1970's the water law was accepted. As a result of foreign pressure the pact on distance trans-border pollution was signed up in 1980's. Furthermore act on protection and exploitation of mineral resources came into being. However, with a view to planned economy peculiarities, proprietorship model and prevailing political priorities environmental problems have been underestimated and mistreated for the long time (see e.g. Ritschelová et al., 2006). Since there was no political demand for relevant data, one can state that environmental statistics at that time was limited to data closely related to agriculture with no particular environmental purpose.

The development of the environmental policy in Europe followed the general trend of moving from end-of-pipe technologies and pollution abatement practices that were prevailing in the 60 's-70's of the $20^{\text {th }}$ century up to the so-called integrated technologies and cleaner production of the last decades. Concerning the Czech Republic mainly administrative methods of environmental policy were used in the beginning of the 90's. The primary transformation of the Czech economy during that period was connected with significant activities aimed at improving the environmental state that belonged among the most problematic in the Central Europe of that time. In the first half of the 90's the important changes of environmental protection, especially in the legislative sphere, took place.

During that period legislation has consequently covered the variety of environmental domains, state institutions and environmental funding processes. In addition to acts establishing the Ministry for the Environment (1989), Czech Environmental Inspectorate and State Environmental Fund (1991) number of environmental regulations either newly appeared, or were updated. The most important legislative regulations included acts concerning waste (1990, 1991, and 1992), air protection (1991), general environment, protection of nature and the landscape, and environmental impact assessment (1992). These were often stimulated by the European legislative framework. In reaction to these processes the CZSO has started regular waste generation survey in 1992.

In the second half of the 90's the First State Environmental policy of the Czech Republic (1995-2001) was developed. It has clearly pointed out the priorities based on the generally accepted environmental protection principles and set up time frames for single aims. Environmental legislative process of that time was predominately 
concentrated on the enforcement of post 1989 acts. One should point out the act stipulating right for environmentally related information was adopted in 1998.

Number of the newly introduced measures enabled to achieve the required level of environmental quality through economic restructuring, decreasing the extent of the chosen economic activities, and implementing the new predominately end-of-pipe technologies. These measures placed very high requirements on number and volume of investment projects financed both form the public and private sources. Under these circumstances the demand for data on environmental expenditures naturally occurred within the variety of stakeholder groups. The CZSO had been collecting relevant statistics since 1986 and therefore could offer respective data.

The development of the legislation in the beginning of the new century was connected to entering the EU. The Second State Environmental Policy was accepted in 2001. It mainly reflected the requirements to the EU members and was predominately focused on the fastest implementation of the European environmental legislation. The policy promoted the sustainable development principles and put stress on incorporation of environmental aspects within the sectoral policies. During that time the Czech legal regulations transposed several tens of European environmental directives. The European accent on sustainability promotion demands complex interdisciplinary data from the so-called environmental accounts among others. At present environmental accounting is one of the most actively developing sphere of environmentally related statistics in the CZSO. According to the Recommendation of the Statistical Program Committee (EC) the regular, timely, production of the key environmental accounts modules is expected from national statistical offices. The CZSO is actively taking part in these activities.

Environmental accounts provide a link between economy and environment. The main guideline for implementation of environmental accounts is called System of Integrated Environmental and Economic Accounts [11]. It is based on the same framework as national accounts [2], [8]. Environmental accounting seems to be the best platform for confronting environmental and economic information and serving as a basis for sustainable development assessment. Only such complex statistical overview of the problem area is capable of supporting sustainability-related decision making at regional and national levels.

The Third State Environmental Policy was accepted in 2004 along with the entering the EU and defined agenda until the year 2010. The contemporary legal system of the Czech Republic responds to all new legal environmental regulations adopted by the European Community. Apart from the so-called administrative tools, one can also see the increasing role of the economic tools represented by fees, environmental taxes, emission permits, etc along with the Czech environmental policy development. Several projects performed by the CZSO were related to these issues as well.

As one can see all the above mentioned institutional conditions during two last decades were actively supporting the interest in high quality environmental statistics. These requirements have also been consequently finding respective reflections in the activities of the Czech Statistical Office. The CZSO environmental department was established in 1993. Its personnel capacity have been fluctuating around 8-9 employees during the whole period of its existence. Today 6 persons are involved into preparation of environmental statistics: 1.5 persons (full time equivalent) are engaged 
into environmental protection expenditure surveying, 2 persons deal with waste survey, 1 person prepares water statistics, and 1.5 persons perform activities in the sphere of environmental accounting.

It is clear that not all environmental domains are covered by statistical surveys. However one should also mention that a significant part of data is being collected from other administrative sources (i.e. ministries and other bodies of the State Statistical Service). In this case CZSO additionally plays an active integrative role that consists in collecting, aggregating and confronting of available environmentally related statistical data. This enables providing a more complete picture of environmental-economic situation in the country.

\section{Own Statistical Surveys and Overtaken Data}

\subsection{Statistical Survey on Environmental Expenditure}

Environmental protection expenditure may be divided into investment and noninvestment (i.e. current) expenditure. For a long period of time environmental protection investment was measured as a part of statistical surveys that weren't primarily focused at environmental issues. For example, during 1986-2001 respective questions were incorporated within the investment survey of the CZSO. One should mention that only investment into fixed environmentally related assets was covered at that time. $[7,8]$

During 1986-1990 environmental investment activities were surveyed both at the macroeconomic level (as total environmental fixed assets investment), as well as at the level of particular investment projects, defined as single constructions and other investment activities leading to improvement of the current environmental state. The latter included all environmentally related constructions with granted construction permission and with the budget over CZK 5 million. Those eventually included constructions individually subsidized from the state budget. Data were currently monitored starting from construction permission grant till final building approval.

All investment activities were broken down into four categories: 1. water quality control, 2. protection of ambient air, 3. waste management, and 4. soil reclamation related to mining and waste dumping activities. During 1992-1995 those were additionally extended by protection activities against physical factors influencing environment, i.e. activities reducing noise level, electromagnetic field intensity, or radioactivity.

The structure of financial sources has been surveyed since 1992. For instance in 1993 the following five categories of financial sources were used within environmental investment activities survey:

1. own sources,

2. loans,

3. support from public budgets,

4. sources from abroad, and

5 . other sources. 
However, one of the shortcomings of this survey was that its results covered only a limited number of constructions. Furthermore single types of financial sources were not unambiguously defined. For example, in case of financial sources obtained from the State Environmental Fund one could classify them as state subsidies, as well as other sources.

Within the framework of harmonizing the survey with the European standards in 1996 the CZSO has changed the environmental investment definition and classification. The new classification became to a large extent similar to the so-called Classification of Environmental Protection Activities (CEPA) adopted by the Conference of European Statisticians in 1994. In this respect environmental investment activities were grouped into 6 categories:

1. water pollution control (excl. groundwater),

2. air pollution control and climate protection,

3. waste management,

4. landscape and nature conservation,

5. reduction of the impact of physical factors, and

6. soil and groundwater protection.

Another important change was connected with the extension of the financial limit of the covered environmental investment types. Since then investment activities with budgets less CZK 5 million were also included. State environmental fund was introduced as an additional financial source, i.e. since 1996 the total of 6 financial source types had been surveyed. National Property Fund was included among other sources.

After the new budget structure was adopted by the Ministry of Finance of the Czech Republic in 1997, its specification of environmental expenditures became very close to the one specified by the CZSO. Particular investment projects survey was cancelled. Through the noticeable progress in the sphere of environmental investment survey methodology, its information capacity was still very limited. In particular due to the fact that it still didn't cover non-investment expenditure.

In 2002 environmental investment survey was performed on the one hand as a part of the annual business survey covering selected production industries and, on the other hand, as a part of the annual survey for government institutions. That year CZSO introduced a new environmental activity classification compatible with the 2000 version of CEPA that has been used up to now. It contains the total of 9 categories, including the following:

1. protection of ambient air and climate,

2. wastewater management,

3. waste management,

4. protection and remediation of soil, groundwater and surface water,

5. noise and vibration abatement (excluding workplace protection),

6. protection of biodiversity and landscapes,

7. protection against radiation (excluding external safety),

8. research and development, and

9. other environmental protection activities. 
Classification of financial resources was also updated in 2002 reflecting the changes in model of economic relations in the country. Such finance sources as loans and financial assistance, and issue of securities, free transfers, nonmonetary deposits, etc. were newly introduced.

One of the most significant changes took place in 2003 when the first noninvestment expenditure data were introduced for the first time. Non-investment data introduction led to adoption of the targeted Annual survey on environmental protection expenditure. These updates enabled more complex presentation of national environmental protection expenditure. One should mention that in the beginning it covered only business sector. Separate Annual survey covering only investment into long-term fixed assets for government institutions was used until 2005. Since 2006 both business and public sector data have been collected by a Single environmental protection expenditure survey (ZP 1-01 survey). [3]

A year later ZP 1-01 survey was additionally extended by environmental fees and charges data. At that time it covered non-financial enterprises in the following fields: agriculture, forestry, mining of mineral resources, manufacturing industry, production and distribution of electricity, gas, water, surface and underground transport, aircraft transport with the number of staff higher than 20 and more (NACE rev.1 codes 01, $02,10-40,41,60,62)$. Furthermore the survey covered all non-financial enterprises in the field recycling of secondary raw material and waste disposal (NACE rev.1 codes $37,90)$ regardless their size. Finally it included all governmental institutions and municipalities with more than 500 citizens (NACE rev. 1 code 75).

Table 1. Survey of Environmental Expenditure in 2003-2009. [Source: CZSO]

\begin{tabular}{|r|r|r|r|r|r|r|r|}
\hline year & $\mathbf{2 0 0 3}$ & $\mathbf{2 0 0 4}$ & $\mathbf{2 0 0 5}$ & $\mathbf{2 0 0 6}$ & $\mathbf{2 0 0 7}$ & $\mathbf{2 0 0 8}$ & $\mathbf{2 0 0 9}$ \\
\hline Number of respondents & 8039 & 11648 & 11463 & 15288 & 15143 & 11467 & 11705 \\
\hline Response, \% & 74 & 57 & 62 & 66 & 82 & 82 & 84 \\
\hline
\end{tabular}

Upon introduction of CZ-NACE rev. 2 in 2008 the current ZP 1-01 survey covers chosen units from CZ-NACE 01, 02, 03, 05-33, 35, 36, 49, 51, 52, 58 with 50+ employees and CZ-NACE 37, 38, and 39 regardless number of employees, municipalities with 500+ inhabitants, budgetary organizations and state funds.

As one can see environmental protection expenditure survey has underwent many phases and experienced multiple methodological changes. Today the CZSO has a relatively extensive time series on environmental investment expenditure (19862009), accompanied by a shorter time series of non-investment expenditure (20032009 for business and 2006-2009 for public sector), as well as revenues from byproducts and services (2003-2009 for business and 2006-2009 for public sector). The survey data is used before all to fulfill the reporting duty within the Structural Business Statistics regulation. It is widely used for preparation of printed publications and variety of electronic outputs produced either by the CZSO itself or in cooperation with the Ministry for the Environment (MfE) of the Czech Republic. One should mention among others such publications as Environmental Protection Expenditure in 
the Czech Republic ${ }^{1}$, Report on the Environment in the Czech Republic ${ }^{2}$, Statistical Yearbook of the Czech Republic ${ }^{3}$, or e.g. Regional Statistical Yearbooks ${ }^{4}$.

The main domestic data users are MfE and Czech Environmental Information Agency (CENIA). Information is also widely used within co-operation with international organizations. For instance based on gentlemen agreement the CZSO regularly fills out OECD/Eurostat Environmental Protection Expenditure 5 and Revenue Joint Questionnaire ${ }^{6}$. One should mention however, that only about 5 percent of required data is being filled out at present. One of the strengths of the survey is that information on environmental revenues and taxes is being collected by its means. Both of them belong to highly discussed topics with a view to political situation in the EU. The first is closely related to Europe 2020 strategy supporting environmental technologies and eco-innovations. The second one corresponds to the so-called environmental tax reform (activities in this field in the Czech Republic have been slowed down lately before all with a view to economic recession and restrictive fiscal policy of the current government).

Concerning the future development in the area of environmental expenditure statistics one should state that under the current circumstances the policy of the CZSO is neither to introduce new surveys, nor to support the extension of existing ones. The aim is not to increase administrative burden as well as not to increase budget requirements. In this respect one should rather expect reduction of survey activities in future. However on the other hand legislative activity at the EU level has a potential to motivate extension and development of the survey under review. This would be the case if Environmental Protection Expenditure Account (EPEA) module would be introduced among others within the environmental economic accounts regulation. National activities aimed at reducing public budgets and international policy supporting environmental activities are the two contradictive factors that would influence the future development in the area of environmental expenditure statistics. One can expect that along with the overcoming of the economic recession impacts interest in relevant statistical data would consequently increase.

\subsection{Waste Production Survey}

CZSO has been making statistical surveys in the field of waste generation and waste treatment since the 80 's. After two single-standing one-time surveys of waste dumps and waste production performed by the former Federal Statistical Office in 1980 and 1987 waste generation surveys have been performed on the regular annual basis since 1992. [9]

Through the number of existing critiques (e.g. coverage only of special and hazardous waste, or publishing only aggregated statistics due to individual data issues,

\footnotetext{
${ }^{1}$ http://www.czso.cz/csu/2010edicniplan.nsf/engp/2005-10

${ }^{2} \mathrm{http}: / /$ rocenka.cenia.cz/stat_rocenka_2009/index.htm

${ }^{3} \mathrm{http}: / /$ www.czso.cz/eng/redakce.nsf/i/statistical_yearbooks_of_the_czech_republic

${ }^{4}$ http://www.czso.cz/eng/edicniplan.nsf/aktual/ep-1\#10

${ }^{5} \mathrm{http}: / /$ epp.eurostat.ec.europa.eu/statistics_explained/index.php/

Environmental_protection_expenditure

${ }^{6} \mathrm{http} / / /$ epp.eurostat.ec.europa.eu/portal/page/portal/product_details/

publication?p_product_code=KS-EC-05-001
} 
etc.) statistical questionnaire on wastes in 1993-1996 period established a relatively good basis for further time series creation. This enabled tracing development in the field of production and management of the certain types of waste in the Czech Republic.

Before 1994 surveys were solely focused at disposal and utilization of waste by establishments in order to eliminate double counting possibility connected with transfer of waste between several economic agents. However, strong demand for flow data related to waste transfers between units resulted in extension of survey in 1995 by introducing the name and identification number of the waste acceptor. Based on confronting acceptor organizations with the registers of dump operators and waste incineration facilities one could identify the way of disposal of up to $60 \%$ of the transferred waste.

The survey covered companies classified according to their principle economic activity by such CZ NACE rev. 1 codes and 01, 10-41, 45, 55, 601, 602, 62, 747, $7481,851,852,90,9211$, and 93 with 25+ employees.

The 1998 statistical survey of waste production and disposal was maximally adapted to the requirements of the new act on waste and its regulations for implementation. The main changes included switching to a new waste catalogue, new coding system of waste disposal and utilization ways. These changes were regarded to be the most complex, e.g. due to the fact that the new coding system was regarded to be relatively complicated especially for smaller economic agents. Additional changes consisted in inclusion of other waste category into survey and extension of number of respondents.

In 2002 a new act on waste entered into force. The newly adopted act fully complies with waste management laws and regulations of the EU. The surveyed data is classified according to groups of the official waste catalogue among others. The survey enables production data on waste generated by enterprises (broken down by hazardous and other waste), waste generated by municipalities (including separately collected categories), waste management (recovery, disposal, etc.). This information is supplemented by data on consumption of waste as secondary raw material for producing selected products.

The 2002 survey population included enterprises and sampled municipalities (CZNACE code 751). The enterprises group covered units with 20+ employees with the principal economic activity in CZ-NACE codes 01, 02, 10-36, 38-41, 45, 502, 55, 601-602, 62, 642, 747, 7481, 851, 852, 9211, and 93. Furthermore, units classified to CZ-NACE 37 (Recycling) and 5157 (Wholesale of waste and scrap) and units classified to CZ-NACE 90 (Sewage and refuse disposal, sanitation and similar activities) with no limit on the number of employees, were also included in the survey.

In order to reduce reporting burden the so-called "rotating model" approach to respondent selection is used since 2009. It consists in regular surveying of the most significant business entities (according to generated waste, business branch, or pursuant to the number of employees). The remaining "rotational" part of respondents is inquired once every three years with the rest of the data being mathematically imputed. This approach enabled reducing of respondent number by almost a half. 
Table 2. Waste Production Survey in 1998-2009 [Source: CZSO]

\begin{tabular}{|r|r|r|r|r|r|r|}
\hline year & $\mathbf{1 9 9 8}$ & $\mathbf{2 0 0 2}$ & $\mathbf{2 0 0 4}$ & $\mathbf{2 0 0 6}$ & $\mathbf{2 0 0 8}$ & $\mathbf{2 0 0 9}$ \\
\hline Number of respondents & 14461 & 17741 & 19085 & 17875 & 17363 & 9787 \\
\hline Response, $\%$ & 64 & 69 & 76 & 81 & 79 & 84 \\
\hline
\end{tabular}

Among the main data users directly using data on waste are e.g. such national institutions as Ministry for the Environment and its affiliate Czech Environment Information Agency, Ministry of Industry and Trade, variety of research and development institutions and, of course, media. The collected data is a part of the following regular publications: Statistical Yearbook of the Czech Republic, Generation, Recovery and Disposal of Waste in the Czech Republic, Regional Statistical Yearbooks, Statistical Environmental Yearbook of the Czech Republic, and Report on the Environment of the Czech Republic among others. The last two publications are joint outcomes of CZSO and the MfE.

Among international users one can name e.g. Eurostat and its data users, as well as national statistical institutions of the EU member states. For more than a decade the CZSO has been transferring waste related data to Eurostat. During 1995-2004 the national data reporting was performed according to the so-called Eurostat/OECD Joint Questionnaire on Waste. In 2006 the environmental statistics department changed the report structure in accordance with EC waste directive for which the CZSO is a national responsible institution. One should expect that the range of possible data users is far more extensive. Since the CZSO publishes the majority of data on its web pages, significant amount of regular data users remain anonymous, since they obtain them indirectly via internet.

Concerning the future development of waste production survey one should mention, that act on waste has been updated recently. The most important changes concern the definition and specification of secondary raw materials. Under the current political and economic conditions producers are getting more and more motivated to transform waste into secondary raw materials and to actively use them as production inputs. In reaction to these changes the CZSO has prepared an update of waste production survey. As a result the new survey would support control and development of national Raw Materials policy due to more precise and complete tracing of material flows of waste as well as secondary raw materials e.g. by covering export and import flows. Under institutional conditions of the Czech Republic the waste statistics is also being currently surveyed by the MfE. However, since its actions are limited by the waste-related legislation, and novelization processes involving number of stakeholders are difficult and time consuming, the MfE has no power to follow the new material flow trends so operatively. This also highlights flexibility of national statistical office in reflecting current socio-economic reality.

Issues of raw materials safety are paid an exceptional attention at the European level at present. Secondary raw materials are looked at as a strategically important input into production process. Under these circumstances one can expect that extended waste (and secondary raw materials) production survey would be consequently improved and developed in future according to various stakeholder needs. 


\subsection{Environmental Accounting}

Key modules of environmental accounting in the CZSO include Air Emissions Accounts, Economy-Wide Material Flow Accounts (EW-MFA), and Module for Environmental Protection Expenditure and Revenue. Pilot projects focused at Environmental Taxes by Economic Activity and Environmental Goods and Service Sector were completed as well. One should state that all these modules are still more or less a work in progress. As it was already mentioned, even environmental expenditure survey that has been developing since 1986 is not complete enough to prepare Environmental Protection Expenditure Account (EPEA) according to the requirements described in [11].

However, wide range of methodological work and pilot applications of respective results is currently performed in all key environmental accounts modules. These activities are actively supported by the Recommendation of the Statistical Program Committee (EC) suggesting to provide regular and timely production of the key environmental accounts modules. Eurostat in its turn provides active financial and methodological support to member countries in order to intensify research and development activities in this area. Since no legal base exists in this problem field, at present the majority of data is based upon gentlemen agreements between Eurostat and national statistical institutions. At present some of them transfer data on chosen modules on the basis of other already existing data sources. For instance those include e.g. data on Economy-Wide Material Flows Accounts (based on data from agricultural, industrial and trade statistics), on air emissions accounts (based on the data of air emission inventories), or data on environmental taxes (based on of tax and government finance statistics).

In the meantime proposal for a Regulation on European environmental economic accounts is discussed. The current proposal concerns only the collection of data on emissions, environmental taxes, and material flow accounting. One can expect however, that other modules would be added in future upon the progress in the field of methodology and pilot application (e.g. Environmental Goods and Services Sector (EGSS), EPEA, energy accounts, Resource Use and Management Expenditure Accounts (RUMEA), water, waste, forest accounts, Environmentally Related Transfers (Subsidies) accounts or probably the most problematic ecosystem services accounts).

The first attempt to compile Air Emissions Accounts in the Czech Republic was performed with the support of project of the Ministry for the Environment in 1998. National Accounting Matrix including Environmental Accounts (NAMEA) integrated framework was used for these purposes. The pilot project covered such pollutants as $\mathrm{SO} 2, \mathrm{NH} 3, \mathrm{NOx}$, and $\mathrm{HCl}$. As a result of the project time series for time period 1992 and 1995 occurred.

The next project took place in 2004-2005 and was focused on data of 1998, 1999, and 2003. Its aim was to make a step forward and to find a way for regular annual compilation of NAMEA for air emissions in the Czech Republic. In this respect a close cooperation with the Czech Hydro-meteorological Institute (CHMI) was established. This project significantly extended the amount of pollutants covered by the NAMEA framework. In addition to previous results such pollutants as $\mathrm{CO} 2, \mathrm{~N} 2 \mathrm{O}$, $\mathrm{CH} 4, \mathrm{NMVOC}, \mathrm{CO}, \mathrm{PM} 10, \mathrm{Hg}, \mathrm{Pb}, \mathrm{Cd}, \mathrm{As}, \mathrm{Zn}, \mathrm{Cr}, \mathrm{Se}, \mathrm{Cu}, \mathrm{Ni}$ were covered 
completely, and $\mathrm{CO} 2$ bio, HFCs, PFCs, SF6 were covered partly. No data were identified for CFCs and HCFCs. Consequently in 2008 another project was completed. At that time NAMEA Air reporting tables containing 1995-2006 time series were reported to Eurostat. All project results were also used at national level e.g. in reports on the environment of the Czech Republic, or for State environmental policy development and assessment. In 2010 NAMEA Air data collection project continued based on a new compilation guide.

The first attempts of Material Flow Accounts (MFA) preparation in the Czech Republic for years 1990-2003 were performed by the Charles University Environment Centre as a part of its research and development activities. In the following years the CZSO in cooperation with Environment Center carried out a common project aimed at routine MFA preparation process development. As a result of this project the Czech MFA time series for the years 1993-2004 were compiled. Data were collected in close cooperation with Ministry of Industry and Trade and Czech Geological Survey among others. At present CZSO disposes of quite extensive economy-wide material flow time series: domestic extraction is covered for the period 1990-2009, import is covered for 1999-2009, and export is covered for 1999-2009 period. In the close future it is also planned to map outputs of the economy.

As it was mentioned, Environmental Taxes by Economic Activity and Environmental Goods and Service Sector statistics are currently in the phase of development. [5] In 2009-2010 the CZSO has got two respective Eurostat grants in order to develop methodology for routine data collection. The aim of the pilot Environmental Taxes by Economic Activity compilation project was to determine data sources for sectoral breakdown of environmental taxes and fees in the Czech Republic additionally broken down into four categories: energy taxes, pollution taxes, resources taxes, and transport taxes. Totally 12 taxes and fees matching the environmental tax definition were specified for these purposes in cooperation with Charles University Environment Center and chosen tax recipients. As a result of the project time series of energy, resources and transport taxes from 1995 to 2008 and pollution taxes from 2001 to 2008 were created in a demanded structure.

Methodology for Environmental Goods and Services Sector data collection was developed in cooperation with Jan Evangelista Purkyne University. The project was focused at possibilities of environmental goods and services related data from yearly industry and production and environmental protection expenditure surveys, core industries conventional statistics as well as government expenditure statistics. As a result of the project time series of environmental goods and services related data for 2005-2009(2008) were developed. Research related to these and other environmental accounting modules in the CZSO would continue in future.

\section{Discussion}

Even through the fact that the extent of voluntary business environmental reporting activities is constantly increasing, the role of the state statistical service in the field of producing environmental statistics still holds its exceptional position. The main reason for that is that only centralized state authority is capable of providing objective, standardized, quality and complete environmental statistics. These 
parameters make it a suitable tool for supporting of decision making at different levels. Furthermore only official statistics can be sufficiently specific and take into account the local conditions as well as particular interests of different policy makers. Being a producer of wide range of other economic and social statistics national statistical office is capable of ensuring the compatibility of different data for the purposes of multidimensional analyses. In this respect official statistics is the most appropriate or even the only data source for promoting sustainable development principles.

One of the critical issues in promoting sustainability consists in analysis of interaction between the economy and the environment. It is widely accepted that the best available approach to the economy description and analysis is based on using national accounting framework. The contemporary System of National Accounts (SNA) is an internationally acknowledged accounting standard at the macro-economic level. The SNA has historically acquired a good reputation of a tool supporting policy-making at different levels. The majority of countries today widely use such SNA-generated indicators for defining objectives and evaluating results of different policies.

The development of the national accounting system has gone a long way from narrow focus at purely economic activities to the wide range of social, economic, and environmental issues. With a view to the constantly changing needs of decision and policy makers as well as other stakeholders, the conventional national accounting system is being constantly transformed and updated in order to meet them.

Significant part of changes is motivated by growing environmental concerns. They have stimulated numerous critiques of the conventional System of National Accounts and brought an idea of linking economic and environmental data. Speaking about the national accounting, the most up-to-date approaches to this linking are discussed in the System of Integrated Environmental and Economic Accounting (SEEA). [2] It comprises several categories of accounts, among which one can find environmentally adjusted accounts. These accounts consider how the existing SNA might be adjusted to reflect defensive expenditure, depletion, and degradation and consequently calculate the environmentally adjusted NDP among others.

Through the common agreement about linking the conventional economic and newly developed environmental accounting systems there is a wide debate about the form of their integration. Some experts argue for the complete greening of national accounts, i.e. integrating environmental concerns into conventional SNA that would consequently adjust main economic indicators. The main argument is that conventional SNA does not provide comprehensive welfare measures and therefore policy- and decision-makers do not get indicators they are actually interested in. Greening of accounts is expected to eliminate this problem.

The other group of experts argues for maintaining explicit distinction between the two accounting systems. The rationale for that is connected with the following two reasons. First, it is the need to maintain consistency with already available historical time series of indicators produced by the SNA. Second, is the conservative principle of accounting preventing from direct incorporation of data retrieved by various nonmarket evaluation techniques into the conventional national accounting.

According to our opinion, the most sensible way is to choose the second conservative approach to linking economic and environmental accounting systems 
and continue using satellite accounts that were firstly introduced in the SNA 1993. The SEEA is still a work in progress containing number of unsolved methodological issues. In number of cases it provides only discussion and/or overview of possible approaches rather than an action plan. Currently the third version of the SEEA is being prepared. However, one can expect that complete consensus on all arguable points would not be reached in this version either. This conservative approach would enable the development of environmental accounting, provide comparable environmental-economic data, and preserve the consistency of conventional national accounts. One should admit that the SNA can not be (and probably should not be) flexible enough to follow all the newly borne concepts and theories.[6]

Additional argument is that environmental accounts are closely related to environmental statistics. In case environmental accounts become part of national accounts the link between accounts in physical and money units may be damaged or become less straightforward. It is a matter of vital importance to preserve direct relation between monetary statistics and physical environmental data. Not only it enables the control of data quality, but it also helps to explain economic processes and provides logical interpretations of different environmental-economic phenomena. In this respect the satellite accounts approach is the right solution for making the whole system more suitable for satisfying the growing information needs of both decisionmakers and other stakeholders involved into variety of issues.

\section{Conclusion}

As one can see political interest in environmentally related statistics has been rapidly increasing during the last two decades. The main reasons for that are twofold. First, the alarming environmental problems required legislative actions. These processes created demand for environmental statistics enabling prioritization of respective problems. On the other hand, environmental actions significantly influence economic activities, motivate structural changes and involve number of other related socioeconomic consequences. These factors created demand for quality environmental accounting information. As one can see, all these institutional conditions were and are still actively supporting the interest in complex environmentally related statistics.

As key integrative part of the national statistics service the Czech Statistical Office has been making active steps to meet these rapidly changing institutional requirements. One should also note that significant number of environmentally related statistics is also collected due to various command and control purposes. Even through the fact that not all environmental domains are covered by statistical surveys, CZSO data accompanied by these data cover the most important spheres of environmental issues.

Regarding the political demand for environmental data and increasing pressure from variety of other stakeholders, the future of environmentally related statistics is determined by setting up a legal background on the compilation of environmental accounts. One can expect that these activities would support development of environmental satellite accounts and provide complex and comparable data for environmental-economic analyses at the European level. These processes, however, would be obviously slowed-down in reaction to the overall economic situation and 
consequent reduction of budgets of national statistical institutions. Furthermore, in conditions of overall administrative burden optimization, actions increasing the reporting burden become less and less politically acceptable. In addition to the current stage of methodological development and preparedness of single member countries, this is one of the main reasons why the currently proposed regulation reduces field of action to the three core modules only, with the rest to be consequently added in future. These contradictory factors would determine development in the field in the upcoming years.

\section{References}

1. Barroso, J.M.: Europe 2020 - Presentation of J.M. Barroso, President of the European Commission, to the Informal European Council of February 11, 2010, http: / / ec.europa.eu/eu2020/index_en.htm

2. Congressional Budget Office. Greening the National Accounts. Congressional Budget Office, Washington, D.C (1994), http: / / www. cbo.gov/ftpdocs / 48xx/doc4886/doc11.pdf

3. CZSO. Indicators on Environmental Protection Expenditure. Agriculture, Forestry and Environment Statistics Department, CZSO, Prague (2008)

4. EUROSTAT. Environmental Statistics and Accounts in Europe. Eurostat, Luxembourg (2010)

5. EUROSTAT. The Environmental Goods and Services Sector. Office for Official Publications of the European Communities, Luxembourg (2009)

6. Leinen, J.: Report on the proposal for a regulation of the European Parliament and of the Council on European environmental economic accounts. Committee on the Environment, Public Health and Food Safety 17 (November 2010),

http: / / www . europarl . europa. eu/sides / getDoc. do? pubRef $=-/ /$ EP / / NONSGML+REPORT+A 7-2010-0330+0+DOC+PDF+V0 / / EN

7. Ritschelova, I., et al.: Environmental Policy. Selected Chapters. Jan Evangelista Purkyně University in Ústí nad Labem, Ústí nad Labem (2007)

8. Ritschelová, I., Hájek, M.: K metodice zjišt’ování výdajů na ochranu životního prostředí. Finance a úvěr 2, 110-117 (1998)

9. Ritschelová, I.: Determinantion of Waste Production in CR. Eurostat - Work session on environmental statistics, Lysebu - Norway, Working Paper No. 13 (1996)

10. Šimonová, L.: Statistika odpadů v ČR a Evropě. In: Žák, M (Ed.) Účetnictví a reporting udržitelného rozvoje (na mikroekonomické a makroekonomické úrovni). pp. 31-34, Linde nakladatelství s.r.o., Praha (2009)

11. United Nations et al. Handbook of National Accounting - Integrated Environmental and Economic Accounting (2003),

http://unstats.un.org/unsd/envAccounting/seea2003.pdf 